\title{
An Assesment of Monetry Policy Transmission Mechanisms in Nigeria
}

\author{
Dr. BitrusNakahBature \\ Department of Economics, University of Jos, Nigeria
}

\begin{abstract}
Monetary policy as an integral part of economic growth and development require effective transmission channels to lubricate the flow of resources to different part of a country in order to achieve holistic development. Both monetary and fiscal policy are relevant in Nigeria. But, the transmission mechanism must be suitable for the type of economythat Nigeria operates. It is our flair in this work to demonstrate our erudition in an important area of modern economy such as the monetary issues that guidesthe behavior of both producers and consumers alike. Our chapter one is the general introduction of the concept of financial system, chapter two treats the transmission mechanism, chapter three examines monetary and fiscal policies and their relevance in the Nigerian economy, chapter four assesses the monetary policy transmission mechanism in a rapidly growing economy like Nigeria. While our conclusion forms the last part of this write-up.
\end{abstract}

\section{Introduction: Background}

The goal of every central bank in the world is to achieve primarily, price stability in the economy. Just like any central bank in the world, Nigeria embarks on inflation targeting regimes in order to respond appropriately to the challenges posed to the various channels of monetary policy transmission mechanism. Thus, the various channels of monetary transmission are important in this work. But, which one is dominant with the highest speed of transmission in Nigeria remains a major academic exercise or explanation. Many writers have expressed their views on individual transmission mechanism in Nigeria. Yet, whatever argument that is displayed, remains a matter of explanation on how output in Nigeria is raised within the shortest period of time as this will be measured by the rate of growth of the economy. No nation in the world enjoys smooth economic growth and development without provoking its people positively towards aggressive production and distribution and/or consumption activities through various investments in the various sectors of the economy.

Nigeria as one of the fastest growing economy in the world today need to be gingered by the financial sector activities as to remain active and at all times irrespective of the huge challenges that are politically distracting the present regime from its transformation agendawhich has not left any sector or facets of the economy untouched.

Our desire in this work is to suggest concretely the approach in monetary policy transformation mechanism that will make the Nigeria Gross Domestic Product (GDP) grow faster. This, in a nutshell will facilitate the achievement of the nation's vision20:20:20 dream. Over, the decades, the corruption activities and lack of awareness hampered the rate of growth in all sectors of the economy. What is clear about the present regime is that it has been working hard to create awareness through seminar, workshops and conferences which is why the way forward for every parastatals and government units have been discussing reasons for the stagnation and proffering solutions or way forward for Nigeria.

It is therefore,pertinentto commend the efforts of the central bank of Nigeria (CBN)like that of any central bank in the world for the practical understanding of how monetary policy actions transmit to real economy. CBN (2010:1) explains that:

The effectiveness of monetary policy critically depends on a proper understanding of the transmission mechanism through which charges in a central bank's policy action affect the economy, in particular, prices and output.

When a central bank takes a policy action, it sets in motion a number of economic events which change the monetary policyas it changes price and output. This is the process that is referred to as the transmission mechanism of monetary policy. For instance, short-term interest rate and aggregate bank credit can help in protecting the system from both domestic and external shocks. Thus, our analysis will also be the discussion of how this transmission process of the CBN will help in adjusting the economy from different types of shocks.

\section{The Financial Sector Of An Economy}

There is no doubt that the existence of a strong and viable financial sector of any economy in the world, explains the strength of other sectors of the economy. Thus, every economy in the world depends largely if not 
totally on its financial sector for the continuous growth of the rest of the sectors. It is the financial sector that stirs other sectors or moderates the rest of the economy.

The global financial crisis caused economy crisis that was difficult to control. World leaders have to embark on bail-outs and other measures to ensure that money got to perform its traditional function of facilitating transactionsworldwide.

Many economies of the world powers crumbled, leaders' positions were threatened, unemployment exacerbated, and debate were all over the globe on how to prevent at the global market from collapsing. There is no doubt that the transmission process of monetary policy arrangement was faulty at the international level. This situation was no doubt a painful one as no nation was sure of the way out of the mess.

Notice that many countries decided to go to the streets asking for the resignation of their leaders which equally coincided with the Arab-uprising that engulf the world into deadly events up to the present time. Any political organization the world over, that wants to survive, must take the welfare of its people serious. The outcome of any failureto use the right measures to adjust the economy by promoting welfare and economic growth and development, can be dangerous and disastrous to the peaceful coexistence and survival of the nation.

\section{The transmission mechanism}

Monetary policy transmission mechanism in Nigeria traces the relationship between changes in the supply of money and real variables such as output, employment, and prices of goods and services. These arguments have been discussed through different theoretical explanation as well as in different channels of transmission. For instance, changes in domestic demand influences current production levels, wages and employment. In the process, it leads to changes in domestic prices as well. Thus the monetary authorities must have a good and reasonable assessment of the time and the effect of their monetary policies on the economy. Let us examine the various monetary policy transmission mechanisms as it affects Nigeria and the degree or the strength of the effects. The transmission mechanism or channels that will be discussed as it affects Nigeria are: interest rate channel, credit channel, exchange rate channels, asset price channel and inflation expectations channel.

\section{The Interest Rate Channel of Monetary Policy Transmission Mechanism}

The traditional classical/Keynesian IS - LM explains how income could be raised by raising the level of investment which can only be done by reducing the cost of money both domestic and foreign in order to raise the demand for money. When the real cost of borrowing over all horizons increases, firms cut down their investment expenditure. Likewise, households who face higher real borrowing cost would scale down their consumption or (borrowing). This would reduce the aggregate demand, output and employment. This is so because the demand for money increases, when the cost of money or interest rate is low. Again, at such a low interest rate, investment will be raised because investors will be willing and keen to borrow due to the low cost of borrowing. Generally, when investment is raised, it means employment has risen which will lead to a rise in income through increases in output Mishkin, 1996 provided the following analogy such that $\mathbf{M} \uparrow \rightarrow \mathbf{i r} \downarrow$ $\rightarrow \mathbf{I} \uparrow \rightarrow \mathbf{Y} \uparrow$

Where

$$
\begin{aligned}
& \mathbf{M}=\text { Money Supply } \\
& \text { ir = Real interest rate } \\
& \mathbf{I}=\text { Investment Spending } \\
& \mathbf{Y}=\text { Output }
\end{aligned}
$$

In his analysis as can be seen above, it is expansionary monetary policy that can lead to greater output, greater employment via greater investment vis-à-vis greater welfare of society.

In an empirical survey by (Taylor, 1995) revealed that the interest rate channel has a strong empirical evidence for substantial interest rate effects on consumer and investment spending. Evidence by European Central Bank (ECB, 2002) indicates that interest rate channel plays an important role in the transmission of monetary shocks. Accordingly, direct and indirect effects of interest rate changes which includes wealth and exchange rate effect on investment explains about 80 percent of the total response of output to monetary stocks after a lag by three years.

In a pass-through of policy rate researched by (Mohanty and Turner, 2008) revealed that most bank consider interest rate as the dominant channel of monetary policy transmission mechanism. In their work, interest rates explain a large part of the short and long run variation in output and inflation in Mexico.

In another development, (Cotharelli and Kourelis, 1994) discovered that:

The pass-through of monetary policy changes is not the same across countries and structural parameters such as competitive structure of the market (costs of switching bank), individual bank policies in relation to market share, deposit structure, business cycle, credit risk and interest rate volatility make the pass-through incomplete. They found that interest rates are quite sticky in the short run and possibly also in the long run. 
It has also been argued by (Angbazo, 1997, Hannan, 1997; and Corvoisier and Gropp, 2002), that:

In less competitive markets, banks might act in a collusive manner and therefore, reach a new equilibrium, after a change in market rates. Added to this, the degree of competition in the banking system affects the level of competition and, therefore, the pass-through.

Another interesting aspect of most of these empirical analyses increases in banks competitions tend to narrow banks lending margin and it makes them more responsive to market rates which should increase the speed and the degree of the pass-through. The importance of the bank credit in monetary policy transmission mechanism has also been stressed and it is presented below:

\section{The Credit Channel of Monetary Policy Transmission Mechanism}

The credit channel relates to bank lending and the bank balance- sheet transmission mechanism. It has direct bearing with commercial banks of a nation or financial intermediaries. It has been argued by (Rodriques, 1993) that:

The behavior of the lending rate becomes less important if the demand for bank deposits is sufficiently elastic. An increase in TreasuryBill rates will move deposits out of the banking system, thus affecting aggregate demand through the availability of credit, rather than through its cost.

The argument disregards that fact in many countries, bank have large buffer government paper that can be sold to counter the effects of deposit changes. Note that the lending mechanism of banks works through the supply of bank loans for investment purposes vis-à-vis employment and output growth. The rate of growth of a nation is also influenced by the actions of banks credit. But the dilemma here is that the tightening of monetary policy by the central bank of Nigeria and elsewhere could reduce the supply of loans for small and medium sized bank-dependant business, which are compelled to search for new lenders so as to establish new credit relationships in order to better their investment scope.

Nigeria 1996 budget for instance raised hot argument that had to do with the issue of whether contractionary monetary policy was the way forward as federal government put it that year as the best way of fighting inflation. Since the policy aimed at reducing the quantum of money in circulation or the expansionary monetary policy as it was argued by the manufacturers association of Nigeria (MAN), since, they believed that it is only the expansionary monetary policy that will put more money in their hands for the expansion of their business through lower costs of borrowing so as to produce more goods and services (output) to be able to deal with the threat of inflation in the country. This is an interesting argument that is seen differently between banks on the other hand, and government on the one side.

Franco-Modigliani and Miller argued in their theorem that, banks lending will depend on banks financial structure and lending opportunities as well as on market interest rates. The effects of monetary policy on bank lending will therefore, depend on the capital adequacy of the banking sector.

It should however be noted here that majority of the business investments in the west African subregion and in Nigeria in particular depends very largely on bank credits availability. Thus, the need to develop the credit activities of commercial banks to sustain this need cannot be over emphasized. Thus, the central bank should be able to influence the supply of loans through the use of monetary instrument positively to satisfy these needs. Firms however should not rely solely on borrowing money from the banks alone, but look inward by borrowing from the general public through bonds.

In research by (Blinder, 1992) who applied VAR analysis to U.S data examine the impulse response function of bank loans, securities, and deposits to positive innovation in the federal funds rate. The result was that:

1. An immediate decline in volume of securities and deposits and a delayed decline in the volume of bank loans following a monetary tightening.

2. Over a longer time span, there is a rebuilding of bank securities holdings and a further decline in loans, essentially matching the decline in deposits.

The general results were found to be consistent with the credit channel, since loans responded with the same lag as unemployment, to the monetary policy shock.

Davla-Norris and Floerkemair (2006) found in their research using VAR that:

The transmission mechanism of monetary policy in America shows that for bank lending channel to work, a monetary policy must effectively limit banks ability to supply loans by reducing banks reserves. That the high excess reserves coupled with the ability to substitute bank reserves with alternative sources of investment funds made the banks unresponsive to contractionary monetary measures.

The balance-sheet channel simply imply that the shape of the marginal efficiency of invest (MEI) curve is a function of the dept-equity ratio in the economy and can be affected by monetary policy. It is believed that both distributional impact of monetary policy and small changes in interest rates impacts on investment. 


\section{Exchange Rate Channel of Monetary Policy Transmission Mechanism}

Changes in exchange rate have implication on the spending behavior of individuals and firms which in turn affect the aggregate demand of goods and services. Under a flexible exchange rate regime, expansionary monetary policy depreciates domestic currencies and increases the prices of imported goods.

A relatively weak transmission mechanism that could affect real output and prices can come about as a result of the strength of the exchange rate channel i.e. the responsiveness of the exchange rate to monetary shocks, the degree of openness of the economy and the exchange rate arrangement of the country.

In an empirical analysis by (Krugman and Obstfeld, 2000), they stated that the exchange rate between the currencies of domestic and foreign countries is equal to the ratio of their respective price levels. It posits that a fall in the domestic currency's purchasing power will be associated with proportional currency depreciation in the foreign exchange market underpurchasing power parity (PPP).

Note that foreign exchange market is a market where buyers and sellers of domestic and foreign currencies are brought together. To Krugman, the equilibrium exchange rate is arrived at when the rate of return on domestic currency deposit equals that of the foreign currency deposit plus expected rate of depreciation of the domestic currency.

In the case of Nigeria (Nwafor,2006), employed a co-integration and error correction methodology to test the validity of the monetary model of exchange rate determination in explaining the relationship between the Nigeria Naira and the U.S Dollar. The result was that for the transmission mechanism of monetary policy through the exchange rate channel in Nigeria has a long run relationship between the exchange rate and the other macroeconomic variable. Thus, a monetary policy-induced change in money supply influences the exchange rate which in turn affects the current account, prices and output.

\section{Asset Price Channel of Monetary Policy Transmission Mechanism}

What is all about this asset price channel? Simply comprises the equity price channel and the housing and land price channel.The equity price channel is further sub-divided into two: that is the investment effect which rely onTobins quantity theory of money and the wealth effect on consumption advanced by Modigliani's life-cycle income hypothesis.

Therefore the investment spending will rise because the firm can buy a lot of new investment goods with only a small issue of equity. The treatment of asset price channel of monetary policy transmission mechanism influences prices more in the market for equities and real estate, and those asset price movements are all capable of generating important wealth effects through spending on output and employment.

Empirical evidence with (Eichengreenn and Tong, 2003) equally confirmed the link between fluctuations in asset prices and changes in monetary policy regimes. In addition (Saxton,2003) also noted that:

Asset prices could mirror prices bubbles since such movements influenced and help predict general price inflation. And if equity prices fall, the incentive to buy stocks or use it as a source of financing investment weakens.

Generally, (Thygesen, 2002) observed that, the transmission mechanism through changes in asset price to the real economy was well understood though difficult to quantifyempirically. Therefore, the three transmission channels through which this could occur are the wealth effect, the Tobin's Q effect and changes in credit through the balance sheet of financial intermediaries. Hence, Thorbecke(1997) discovered that an expansionary monetary policy increased ex-post stock returns and that with a low interest rate, firm's economic activity increased, leading to larger cash flows and higher returns. Let us now take on the fifth monetary policy transmission mechanism which has to do with inflation.

\section{Inflation Expectations Channel of Monetary Policy Transmission Mechanism}

Inflation expectation transmission mechanism is another strong mechanism for monetary policy in this analysis. They are transmitted into the economy when firms adjust their prices in response to their perception of how future prices would trend. It has been argued in some quarters that, a well-anchored inflation expectation is essential for the securing of price stability and facilitating overall economic stability. Thus, with well anchored expectations, monetary policy can easily respond to stocks and central banks would have greater flexibility in responding to financial market disturbances.

Furthermore, the commitment of monetary policy to reduce inflation is credible, if its effectiveness is enhanced by its potential to reshape inflation expectations.

In an inflation empirical analysis done by (Blanchflower, 2008) revealed that inflation expectations were strongly influenced by past experiences while evidences of future path of prices were highly correlated with an individual's evaluation of current inflation.

It was also established in a study by (Goelton,2008) that the transmission mechanism of the monetary policy in Indonesia established that expected inflation is determined predominantly by exchange rate, past 
inflation and the interest rate. In addition, (Mayes,2004) in his analysis of the monetary policy transmission mechanism in the Baltic states established that monetary action exerted effects on the economy through their on the confidence and expectations of economic agents about the future outlook of the economy.

Finally the monetary policy transmission mechanism shows how well the monetary instruments as applied by the apex banks in the world and other financial institutions help to organize the economy particularly on their path to growth and development. It then follow that the financial sector of an economy determines the strength of the economy especially when talking of provoking the economy positively with its instruments and /or the various transmission mechanism.

\section{The Monetary Policy and Fiscal Policy: The Monetary Policy}

Monetary policy in Nigeria has been influenced by the macroeconomic environment especially the stance of the fiscal policy. There is no how we can talk of monetary policy issues without reflecting on the fiscal policy. In certain years in the past, the history of monetary policy and fiscal policy in Nigeria show that during some years, the government embarked on either monetary policy or fiscal policy to run the economy as the best way of dealing with the each problem at every particular time or years.

There was a fiscal dominance in some years in Nigeriawhich showed a partial disappearance of the monetary policy. CBN (2010) presented the following analogy that is so relevant in this work that:

Over the years, there has been the problem of fiscal dominance which most often hampers the effective implementation of monetary policy, especially prior to 1999. Consequently, monetary targets have been missed in most of the years. However, 2004 witnessed the beginning of improvement in governments' fiscal profile and this complementary role resulted in the achievement of broad money targets in 2004 and 2005

After these years, monetary policy took over the gingering of the Nigeria economy up to the present year of this publication. What interests us most is the fact that the two policies (monetary and fiscal) are generally interrelated by the assessment of the present time needs of the economy and the two can be used to bulldoze the economy.

\section{The Fiscal Policy}

While monetary policy targets macroeconomic variables such as:

1. Employment raising or unemployment lowering.

2. Price stability such as exchange rate, inflation rate, interest rate etc.

3. Income distribution between the poor and the rich. Otherwise the rich would hold the country and the polity to ransom.

4. Economic growth interms of the Gross Domestic Product (GDP) Gross National Product (GNP) etc.

5. Balance of payment (BOP) required such as a favorable BOP all the times.

The fiscal policy on the other hand is concern with what the political arm of government can do for the people. In fact, it handles the provision of goods and services for the people, provides infrastructure and amenities. This is because the taxes and royalties collected by government are expected to be used in changing the life quality of the people or the citizens.

Hence, while the monetary policy is the foundation, the fiscal policy is the building. The whole building rests on the foundation. That is to say that, the laws and order, provision of the security of the citizens rest squarely on the solid foundation which is the monetary policy. The building can only stand, if there is a solid foundation. If the foundation is faulty, all other things will be faulty.

Note that in order for government to finance its national projects, the government can decide to raise taxes given the rise in income provoked by the monetary policies available. It all depends on the various economic activities which include viable investments that are facilitated by the availability of funds provided by lowering the cost of these funds. Recall that the higher the cost of fund, the lower the borrowing rate, and the lower would be the level of investments and vice-versa

\section{An Evaluation of the Monetary Policy Transmission Mechanism in Nigeria}

The different channels of monetary policy transmission has been discussed, the dominant channel which is the highest speed of transmission in Nigeria has been identified as the interest rate. Others are relevant but require a lot of government efforts put in it,given the interest rate channel, the exchange rate channel, the credit channel, the asset channel and the inflation targeting channel.

For peculiarity, the Nigeria economy is GDP oriented and GDP has been disaggregated into oil and non-oil GDP, we have to rely on some findings that:

1. The credit to the core private sector (CCPS) granger cause inflation, real GDP but does not granger cause inflation

2. That a shock to CCPS causes positive and sharp increase in output and prices but with a slow speed of reversion 
In general, our analysis show that the exchange rate channel is weak compared to the credit channel. Our view about those channels of monetary policy transmission mechanism is that Nigeria economy requires a lot of credit from banks to small and medium businesses as well as individual businesses. Therefore, the credit channel should be first followed by exchange rate which facilitates business and investments across borders, the interest rate, asset prices, and inflation expectation. This is our view which did not stop other people's views, the emphasis on our view is that, the credit channels has the advantage of banks playing a special role in the financial system by mobilizing deposits as well as granting loans. The higher the money supply in this direction, the higher will be the bank reserves, which will lead to higher loans vis-à-vis the higher the investment as well as greater output expectation which will also lower inflation.

\section{Conclusion}

Effective monetary policy transmission mechanism will among other things facilitate the growth of an economy such as that of Nigeria. The various transmission mechanisms have their relevance differently and not all of them are effective or even exist in some countries of the world. If the measure did not work in one country, it does not mean that it will not work in another country. The financial environment determines to a large extend the workability of any policy.

\section{Reference}

[1] Angbazo, L. (1997). Commercial Bank Net Interest Margins, Default Risk, Interest-rate risk, and Off Balance Sheet Banking, Journal of Banking and Finance, 21, 55-87

[2] Bermanke, B. and Gertler, M. (1989). "Inside the Black Box: The Credit Channel of the Monetary Policy Transmission," Journal of Economic Perspectives, Vol. 9, No. 4, pp. 27-48

[3] Blanchflower, D. (2008), "Inflation, Expectations and Monetary Policy", A presentation at the David Hume Institute of Royal Society of Edinburgh, 29 April.

[4] Carvoisier, S. and R. Gropp (2002). Bank Concentration and Retail Interest Rates, Journal of Banking and Finance, 26(11)

[5] CBN (2010). "Monetary Policy Transmission Mechanism in Nigeria"

[6] Cotrelli, C and Kourelis, A. (1994). "Financial Structure, Bank Lending Rates and Transmission Mechanism Policy" IMF Working Paper, 94 (39)

[7] Dabla-Norris, E. and Floerkemier, H. (2006). "Transmission Mechanism of Monetary Policy in Armenia: Evidence from VAR Analysis" IMF Workng Paper, WP/06/248

[8] European Central Bank (2002). "Monetary Bulletin"

[9] Hannan, T.H. (1997). "Market Share Inequality, the Number of Competitors, and the HHI: an examination of bank pricing, Review of Industrial Organisation, 12, 23-35

[10] Krugman. P.R. and Obstfeld, M. (2000). International Economics: Theory and Policy. Addison-Wesly Publisher

[11] Mishkin, F.S. (1996). "The Channels of Monetary Transmission: Lessons for Monetary Policy". Banque De France Bulletin Digest. No. 12, March

[12] Modigliani Franco (1971). "Monetary Policy and Consumption, in Consumer Spending and Monetary Policy: The Linkages", Boston, Federal Reserve Bank of Boston, pp.9-84

[13] Mohanty, M.S. and Turner, P. (2008). "Monetary Policy Transmission in Emerging market Economies: What is New?". In: "Transmission Mechanism for Monetary Policy in Emerging Market Economies" BIS Papers, No. 35.

[14] Rodrigues, A. (1993). "Government Securities Investment of Commercial Banks. Federal Reserve Bank of New York Quarterly Review, pp.39-53

[15] Saxton, Jim (2003). "Monetary Policy and Asset Prices" (R-NJ) Joint Economic Committee United State Congress, April".

[16] Taylor, J.B. (1995). "The Monetary Transmission Mechanism: An Empirical Framework. Journal of Economic Perspectives. Vol.9, No. 4 , pp. 11-26

[17] Thorbecke, W. (1997). "On Stock Market Returns and Monetary Policy". Journal of Finance, Vol. 52. Issue 2.

[18] Thygesen, N. (2002). "Asset and Property Prices and Monetary Policy; A Reassessment? A note for the Committee and Monetary Affairs of the European parliament. Third Quarter.

[19] Tobin, J. (1969). “A General Equilibrium Approach to Monetary theory”. Journal of Money, Credit, and Banking, February, Vol. 1, pp. $15-29$ 